\title{
Character education in the folklore of South Kalimantan (the perspective of literary sociology)
}

\author{
Haswinda Harpriyanti ${ }^{\text {a,1 }}$, Kamariah ${ }^{\text {b,2 }}$ \\ a,b STKIP PGRI Banjarmasin \\ ${ }^{1}$ windabpost@gmail.com, ${ }^{2}$ kamariahm.pd@gmail.com
}

\begin{tabular}{ll}
\hline Informasi artikel & ABSTRAK \\
\hline Keywords: & This study is focused to reveal character education in the folklore of \\
character education, & South Kalimantan. the matter will be examined in this study are: (1) \\
folklore, South & How character education that relate to yourself?; (2) How character \\
Kalimantan, sociology & education that relate to our fellow humans?; and (3) How character \\
& education related to the environment?; The methods used in this \\
research is descriptive analysis method. The techniques used for data \\
collection are the techniques of exploration. The data in this study is a \\
collection of the folklore of the South Kalimantan, published by \\
Lembaga Pendidikan Banua Banjarmasin, the mold is second in 2006 \\
and third in 2008 mold. The result of this study is there are few of \\
character education values mentioned, divided by three object: that \\
relate to yourself hard work, curious, responsible, independent, \\
entrepenuer,); relate to our fellow human beings (obedient, social care, \\
democratic); and relate to the environment (care for the environment). \\
\hline
\end{tabular}

\section{INTRODUCTION}

The term character education appears on lately after a moral degradation afflicting the nation of Indonesia. Starting from here, the Government eventually made a new policy to incorporate the values of character education in any learning in school. Character education should be put in its entirety with the development of the national character and in this regard how important the institution functions as a part of srategis. Suyanto in Kurniawan (2013:31) suggests, "character education character education as a plus, namely involving aspects of knowledge (cognitive), feeling, and action". It can be said that the character education in an effort to make the character or conduct of a person who is obviously good for himself as well as others and the environment.
Sociology is a science of literature examining the relationship of the author with the papers it produces. Based on that, the objects become research sociology literature is literature itself, and social symptoms. In other words, the sociology of literature examines social phenomena existing in the literature.

Literary works that are discussed in this study with regard to folklore. Folklore is a long prose form of oral tradition. As a literary genre of oral, folklore has many benefits for the community. In it embodied the values of education as well as the moral values that are useful. Folk tale or Folklore in South Kalimantan, Banjarese quite a lot number, is a cultural asset is priceless. These are just some of the folklore that has been written and published, the majority again is still a folk oral literature which is spread in the community as 
a culture that is not written. When the folklore doesn't response in writing, then it was feared at one point later this folklore will become extinct or are experiencing changes in the evolution of the content and the way of the story. In the book the folklore of South Kalimantan there is some collection of folk tales in Banjar language. Folk tales in this book recounts the events in ancient times, the story always gives the value of the stories that can be taken by the reader. This research to unearth the knowledge of character education are found through the folklore of South Kalimantan as an object of study. Character education is related to the social and moral values certainly has positive value to the reader.

\section{METHODOLOGY}

The methods used in this research is descriptive analysis method. "The descriptive Method of analysis is done by way of describing the facts which are then followed by analysis" (Ratna, 2015:53). A descriptive analysis of not only outlines but also provide insight and explanations. This is done through the analysis of Folklore in South Kalimantan by emphasizing character education contained in the folklore. Folklore is analyzed then elaborated and researchers offer an explanation so that the method can be understood through character education found in folklore.

The techniques used for data collection are the techniques of exploration.

Technique exploration of means aimed at digging up information in depth or detail of the folklore of South Kalimantan is related to the formulation of the problem of character education in touch with yourself, character education-related a fellow human being and character education related to the environment. In accordance with these techniques, then there are several stages which is done as follows.

1) reading of the folklore of the South Kalimantan from beginning to end repeatedly to obtain a thorough overview.

2) records every quote Folklore South Kalimantan that correspond to the problem raised in the form of a sentence and a paragraph or paragraph intact.

3) identify with the way elections and sorting parts of the data to be analyzed. This stage aims to take required data only in accordance with the research problem.

The data in this study is a collection of the folklore of the South Kalimantan, published by Lembaga Pendidikan Banua Banjarmasin, the mold is second in 2006 and third in 2008 mold. As for the title contained in the collection of the folklore is folklore titles and nine researchers only examined the seven titles of folklore as follows.

a. Galuh Rumbayan Amas (Code GRA)

b. Asalnya Gajah Kada Ada di Kalimantan (Code AGKAK)

c. Mancari Bagandang Nyiru (Code MBN)

d. Si Cupak Lawan Si Gantang Badua Baading (Code SCLSGBB)

e. Radin Sukar Sangsang (Code RSS)

f. Kisah Luuk Naga (Code KLN)

g. Asal Mula Iwak Pipih Banyak Batulang (Code AMIPBB)

The source of the data in this study can be described as follows. 

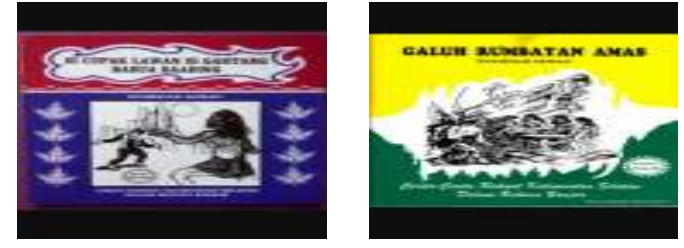

Book 1

The title of the : Si Cupak Lawan Si Gantang

Badua Baading

Category : Folklore

Author : Syamsiar Seman

Publisher : Lembaga Pendidikan Banua

Banjarmasin

ISBN : :

Thickness : : 43

Book 2

The title of the : Galuh Rumbayan Amas

Category : Folklore

Author : Syamsiar Seman

Publisher : Lembaga Pendidikan Banua

Banjarmasin

ISBN $\quad: 978-602-96540-8-0$

Thickness : : 48

\section{RESULT AND DISCUSSION}

\section{The Analysis Of Character Education That}

Relate To Yourself On The Folklore Of

\section{South Kalimantan}

In this study found character education related to themselves i.e., work hard, be curious, responsible, independent and entrepreneur. Following the exposure of his analysis.

\section{Hard work}

Hard work is not easily give up attitude in accomplishing something and mean it.
[1] Baisian kakanakan nang pina recap nitu, halus-halus pulang, maulah Agap lawan bininya jadi kipuh jua lawan gawian. Tagal biar kaya damintu Agap lawan bininya sayang bangat lawan kakanakan samunyaan. Agap tatap haja bahuma banih dipahumaan, bakabun lawan manukil puhun hanau gasan baulah gula habang (01/GRA/2006: 7).

[Have children young, making the Agap and his wife are busy with work. Nevertheless a pity and his wife Agap with his children. Agap still plant rice in the rice fields, fetching water gardening and nira invoked enau to make Palm sugar] (01/GRA/2006: 7).

Quote [1] explained that with so many children belonging to Agap and his wife make Agap still work even harder. The attitude of hard work shown Agap with planting rice in the rice fields, fetching water gardening and nira invoked enau to make Palm sugar.

[2] Si Cupak bagagas maambili adingnya si Gantang. Lawang kurungan nang bajarajak batang rukam baduri nitu dirintaknya sing gancangan sampai taburahai (04/SCLSGBB/2008: 15).

[Cupak of rushing to pick up his younger brother Gantang. The door of the cage that rukam barbed spikes it in actions very toned up dispersed] (04/SCLSGBB/2008: 15).

Quote [2] explains that the Measures being not easily give up when he wanted to save his brother from the evil of Datu Layuh. The Measures mean it against Datu Layuh and his wife. Breakfast buffet how hard work done the quarts of to save and pick up his sister.

[3] Ning Kurungan manimbai lunta, limbah nitu manarik, kadada 
iwaknya nang sangkut. Ditimbainya pulang lunta nitu ka tangah, ditariknya kadada pulang iwaknya nang takait. Pitung kali sudah lunta ditimbai, limbah ditarik kadada iwaknya nang sangkut. Sanunuhan ada iwaknya, matan iwak kalatau nang halus nitu banarai. Inya gin iwak kalatau nitu gugur pulang ka banyu, inya tambus di luang lunta (06/KLN/2008: 31-32).

[Ning Kurungan throwing nets, after pulling it turns out there is no fish were caught. She is thrown again grate into the Middle, pull it in but no longer fish ensnared. Seven times already thrown, after the nets pulled but no fish were caught. Although there are fish, betta fish are only small fish, betta's escape from bondage, FishNet holes] (06/KLN/2008: 31-32).

Citations [3] gives a picture of how Ning Kurungan and his wife are hard at work looking for a side dish of fish for feeding his family. Although several attempts but did not get a fish, they don't give up.

Hard work is not easily give up attitude in accomplishing something and mean it. Shows an earnest effort in overcoming various obstacles in order to accomplish something. The character of this hard work is found in the story Galuh Rumbaya Amas (GRA), Si Cupak Lawan Si Gantang Badua Baading (ACLSCBB), and Kisah Luuk Naga (KLN).

\section{Curious}

Want to know is the attitude and action to know more of what is learned, heard or seen. Inquisitive would something cause someone will approach, observing or studying something else. Human beings are always trying to find the truth, before human beings find their truth must have the curiosity towards the truth.

[4] Balalu dihintipnya laang nang bajarang di dalam rinjing nitu. Sakalinya ada bibinian anum pitung ikung banyaknya nang rahatan manculiti banyu laang nang bajarang dirinjing (01/GRA/2006: 4).

[Then peek Agap nira water is being boiled in a pan. It turns out there are as many as seven young women who were tasting water nira being boiled] (01/GRA/2006: 4).

Quote [4] and describing the curiosity Agap, when heard the story from his mother who said that seven days is, nira water in the Pan when the night seemed on the wane. Then the Agap peek to find out the truth. Agap curiosity answered when I saw there were seven women who were sampling the water boiled in the nira wok. Seven of these women was the son of the ghost kuntilanak. It turns out that causes water tasting is due to reduced nira by kuntilanak ghost kids. Want to know the characters found in the story Galuh Rumbaya Amas (GRA).

\section{Responsible}

Responsible is the attitude and behavior of a person to perform the duties and obligations towards oneself, society, environment, country and God. Responsibility is an obligation which is embedded a person from the outside, someone who chooses to act so that he should be held accountable.

[5] Si Cupak taganang lawan adingnya si Gantang nang sasaurangan di punduk, 
manunggui inya tulak ka hutan mancari burung. Inya taganang, si Gantang musti rahatan bamasak nasi (04/SCLSGBB/2008: 5).

[Cupak remembered by his brother That alone in gantang stops he goes to the forest looking for birds. $\mathrm{He}$ remembered, Gantang sure is cooking rice] (04/SCLSGBB/2008: 5).

Excerpt [5], describes how the Cupak as a sister who is responsible for his younger brother Gantang. Because they live only two, then Cupak who should be responsible for maintaining and taking care of his sister. Everyday Cupak looking for birds to eat him along side his brother.

[6] "Ampun ulun raja. Nangapa ulun dikiau?"

"Pilanduk, ada habar nang manyakitakan hati", ujar raja.

"Habar nangapa nitu, tuanku?"

"Danau wadah hamba rakyat bubuhan iwak nitu cagar baubah jadi danau banyu panas", ujar raja Biruang Hirang.

"Imbah nitu kaya apa, raja?", ujar pilanduk batakun.

"Ikam wayah hini jua lakas tulak ka danau nitu. Suruh samunyaan iwak nang bagana di danau nitu lakasi baalih".

"Ka mana baalih, tuanku?"

"Turun ka batang banyu di bawahnya. Ayu lakasi ka situ" (07/AMIPBB/2008: 38).

["Sorry my King. There is what I called?"

Kancil any news that hurts the heart ", said King.

"What is it, Lord?"

"The people's servants place Lake fish it will turn into a thermal lake", said the King of black bear.

"After that, the King?", said the kancil asked.

"You now also quick going to the Lake it. Go tell them move ".

\author{
"Where, Lord?" \\ "Down to the water below it. Let's \\ go quickly thither "] \\ (07/AMIPBB/2008: 38).
}

Excerpt [6] describes how the attitude of the King of the black bear responsibility for its people. Heard of that offence, the King immediately think of how the best path to its people. Then he ordered the kancil to convey his decision to let the fish move to the water that is in the bottom of the Lake. Responsible character is found in the story Si Cupak Lawan Si Gantang Badua Baading (SCLSGBB) and Asal Mula Iwak Pipih Banyak Batulang (AMIPBB).

\section{Independent}

Standalone is the attitude and behaviour that is not easily depending on others to complete tasks. Standalone means it can do everything alone without the help of others.

[7] Nang badua baading nitu maharagu dua ikung burung sampai masak. Limbah nitu masak nang badua badangsanak nitu makan baimbai saling nyamanan. Makan nasi hangat lawan lauk burung masak babanam. Cacahannya buah asam tandui baracik bacampur banyu uyah (04/SCLSGBB/2008: 5-6).

[Two brothers cooking two birds to cook. After cooking, the two brothers shared a meal with gusto. Eat warm rice and courses: grilled bird. With sauce young and fresh mango fruit mixed brine] (04/SCLSGBB/2008: 5-6).

Excerpt [7] describes how Cupak and Gantang who did everything just two. Moreover, after losing his father, mother and 
their independent living. Looking for a side dish to eat, Cook, and pick up the water in the well. A standalone character found only in the story Si Cupak Lawan Si Gantang Badua Baading (SCLSGBB)

\section{Entrepreneur}

Entrepreneur is the Act of being a businessman, entrepreneur means having power efforts to trying to carry out a job.

$[8]$

\begin{abstract}
Kimas Lalana dilajari badagang, dilajari jua bakapal tulak kamana-mana badua lawan juragan Balaba.

Kaia-annya, Kimas Lalana sudah ganal, jadi urang anum nang gagah, bisa lawan pintar jua sudah badagang (05/RSS/2008: 23).
\end{abstract}

[Kimas Lalana taught the trade, taught also ship everywhere both with skipper Balaba.

After great already, Kimas Lalana became a dashing young man, able and clever in the trade] (05/RSS/2008: 23).

Excerpt [8] illustrates that Kimas Lalana has entrepreneurial souls. Thanks to skipper Balaba who taught him the trade until he finally became a clever youth entrepreneurship. In addition to selling kitchen ingredients such as onion, garlic, tamarind, coconut oil, rice, tea and coffee, Kimas Lalana also sells fabrics, gloves and caps. This entrepreneur's character found only in the story Radin Sukar Sangsang (RSS).

\section{The Analysis Of Character Education That}

Relate To Fellow Human Beings On The Folklore Of South Kalimantan
In this study also found character education that relate to our fellow humans i.e. attitude, aware of the rights and obligations of ourselves and others, strict social rules or social care, appreciate the work and the achievements of others, polite, and democratic. Following the exposure of his analysis.

\section{Obedient}

Submissive and obedient attitude according to the rules, attitudes and action want to give help to other people in need.

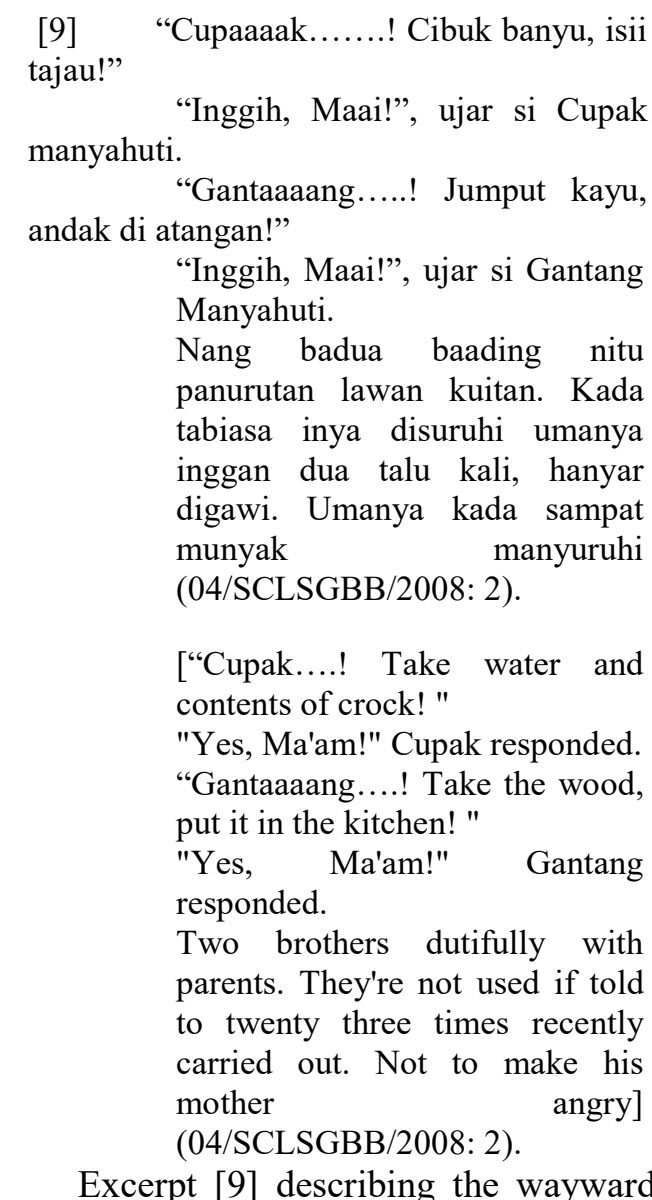
attitude which is owned by Cupak and Gantang. The non-compliant attitude shown Cupak and Gantang When his mother was sent to fetch water and fill the crock, then take the wood. Because their attitude is her mother never got angry when asking for help or telling 
them. That is one good example that could be emulated how subservience to parents. This obedient characters found on the story $S i$ Cupak Lawan Si Gantang Badua Baading (ACLSCBB).

\section{Social Care}

Social care is the attitude and action want to give assistance to people and communities in need. Social care is a form of good deeds against fellow like share, help, and make it easy to do good Affairs.

Imbah mandangar
pidatu Raja Biruang
nitu, samunyaan
binatang rakyat
manangisan pulang
barataan. Katakutanan
bangat, nang cagar
didatangi dikalahi-i ulih
bubuhan gajah.
Sakalinya balalu baucap
burung putih.:
"Ampun ulun, Raja!"
"Nangapa kahandak
ikam, Burung Putih?",
ujar Raja Biruang.
"Ulun mausul supaya
kita mangirim taring
raja", ujar Burung Putih
(02/AGKAK/2006: 13-
14).
[After hearing the
speech of King of the
Bears, all animals
people cry more. They
fear the Elephant King
is attacked by cluster.
White Bird says: "Sorry
I, King!"
"What'd you, White
Birds?", says the King
of Bears.
"I give the motion so
that we send canine
King", according to the
White Bird]
(02/AGKAK/2006: 13-
14).

Excerpt [10] explains how the actions of white birds that are also concerned with what people experienced the beast and the Kings of the bear. The White Bird helps by giving advice that they should send the canine King bear. The attitude of the White Bird who care is a very good social attitudes to emulate.

[11] Urang kampung balalu datangan sabarataan. Ada nang mambawa parang, tumbak lawan karis. Ada jua nang mambawa nyiru. Nyiru nitu balalu dicatuk lawan kayu bapangkih, digandangakan sambil mangiau ngaran si Mawan.

"Mawaaaan....! Buliiiik....!", ujar urang kampung.

Nyiru nitu dicatuk, bagandang sambil mangiau ngaran Mawan. Dikiau bahangkui.

"Mawaaaan....! Buliiiik....!", dikiau pulang (03/MBN/2006: 23).

[All the people came. Brought a big knife, spear and Kris. There is also a carry Purifier rice. Purifier rice was then hit with the wood, at 7 a.m. while calling the name Mawan

"Mawaaaan ...! home again ...! "shouts the man village. the tool was struck rhythmically while calling name Mawan. The harder is called.

"Mawaaaan ...! Home again ...! ", called again] (03/MBN/2006: 23).

Excerpt [11] excerpt illustrates that the community or the people of the village there is 
very caring towards others who are affected.

When hearing the news that their missing, Mawan directly responds and helps search for Mawan. There is a carry large knives, Spears, and Kris. There is also a carry Purifier rice, while struck with wood and is emitted. They shouted calling name Mawan.

[12] Sakalinya urang kampung nitu datangan sing banyakan.

Bubuhannya ada nang mambawa tumbak, ada nang mambawa parang, ada nang mambawa pamangkung batang galam, ada jua nang mambawa tali bilaran tapah.

urang kampung.

"Ayuuuuuu.....bunuuuh....", ujar

"Ayuuuuuu.....bunuuuh.....timpa

aas....., ujar nang lain manyahut.

Urang kampung datangan batambah banyak.

Datu Layuh balalu dipasung bubuhan urang kampung (04/SCLSGBB/2008: 17).

[It turns out lots of people came. They brought spear, brought a big knife, brought from the beater stem galam, there is also a carry strap bilaran tapah.

"Come on ... kill ...", said the people of the village.

"Come ... skewers ...", said the other responded. The villagers come abounded.

Datu Layuh and then tied up by people of the village] (04/SCLSGBB/2008: 17).

Excerpt [12] gives a picture that the people of kampung have behavior and attitude of social care. That attitude they show when they give aid when Cupak has managed to cripple the Datu Layuh. They helped bind the body Layuh the great Datu.

[13] Juragan kapal nang bangaran Balaba malihat Radin Sakar Sungsang parak kapalnya, balalu ditagurnya:
"Kanapa ikam manangis?"

Radin Sakar Sungsang kada

kawa manyinggai. Inya

kasakitan kapalanya nang luka

sambil mamusut lawan tangannya.

Juragan Balaba ada kasian malihat Radin Sakar Sungsang nang masih kakanakan nitu. Inya lawas manjanaki Radin Sakar Sungsang. Dalam hatinya bapikir, Radin Sakar sungsang naya kada sambarangan kakanakan. Biar inya masih kakanakan, tagal ada baisi ciri-ciri nang urang katurunan bangsawan, katurunan nang baik (05/RSS/2008: 22-23).

[Skipper of the vessel, named Balaba see Raden Sakar Sungsang near the boat, then or he:

"Why are you crying?"

Raden Sakar Sungsang speechless is unable to respond. He's in pain wounded while stroking her head with her hands.

Skipper Balaba pity look Raden Sakar Sungsang who are still children. It views Raden Sakar Sungsang while thinking in their hearts, Raden Sakar Sungsang This is not just any children. Although he was little, he had a distinctive lineage and descent are good] (05/RSS/2008: 22-23).

Excerpt [13] describes how the attitude of social care in the show by skipper Balaba. When looking at Raden Sakar Sungsang crying out in pain she felt pity and compassion, then skipper Balaba treat wounds that exist on the head Raden Sakar Sungsang.

[14] "Pipih! Pipih! Kami sudah lapah kaya apa?", ujar iwak nang lain. Iwak nang lain lagi baucap jua kalapahan, kauyuhan.

"Nang maulah ikam lapah nitu lantaran barat mambawa tulang", ujar pipih. 
"Imbah nitu kaya apa?", bubuhannya batakun.

"Kumpulakan tulang ikam barataan, biar haja aku nang mambawanya", ujar pipih (07/AMIPBB/2008: 39).

["Pipih! Pipih! We're tired of what? ", said the other fish. Other fish also said fatigue.

"That makes you tired because of the weight of carrying a bone", said the pipih.

"Then how?", they ask.

"Collect the bones of you all, let me just say I that brought him", Pipih said ] (07/AMIPBB/2008: 39).

Excerpt [14] explains the attitude of the social care who owned the fish pipih. That attitude demonstrated by the attitude of the fish pipih who cares to his friends. Fish pipih help when her friends are in trouble. As the fish swim to exhaustion, then fish pipih bones that bring them to his friends not to fatigue.

The attitude of care and help each other badly needed once in a relationship of community. In the book collection of the folklore is found many stories that can be used as a guide in life. Social care characters can be found in the story Asalnya Gajah Kada Ada di Kalimantan (AGKAK), Mancari Bagandang Nyiru (MBN), Si Cupak Lawan Si Gantang Badua Baading (SCLSGBB), Radin Sukar Sangsang (RSS) dan Asal Mula Iwak Pipih Banyak Batulang (AMIPBB).

\section{Democratic}

Democratic is a way of thinking, behaving, and act the same rate between the rights and obligations of himself and others.
Democratic is behavior that we should apply in everyday life and a country.

[15] "Kita mambawa sisik iwak sanggang talu buting, julung lawan Raja Gajah, nyaman inya tahu", ujar Burung Halang.

"Gasan nangapa sisik iwak sanggang nitu?”, ujar Raja.

"Nitu tandanya awak bubuhan kita tahan diigut, tahan diukang”, ujar Burung Halang.

Imbah nitu kalihatan Raja biruang pina bapikir.

“Ayuha! Aku taparukui haja!", ujar Raja Biruang (02/AGKAK/2006: 12).

["We brought three fish scales sanggang, give it to the King of the elephants, so that he would know ", said Eagle.

"To what fish scales sanggang?", said the King.

"It is the mark of our bodies hold bitten", said Eagle.

After that it looks like the King of the bears was thinking.

"Alright! I concur and agree only!", said King Bear] (02/AGKAK/2006: 12).

[16] "Ulun mausul supaya kita mangirim taring raja", ujar Burung Putih.

Raja Biruang nitu kaliatan pina bapikir satumat, imbah nitu inya baucap:

"Ayuha! Taparukui haja aku", ujar Raja (02/AGKAK/2006: 14).

["Me to suggest that we send a canine King ", said the White Bird.

The King Bear visible thought briefly, after which he said:

"Alright! I accept and agree ", said King] (02/AGKAK/2006: 14).

[17] "Kita bawa ka banua subarang nitu bulu landak, Ulun saurang kainanya nang mambawa, manjulung lawan Raja Gajah”, ujar pilanduk.

"Hauuuuuuuuu........", ujar binatang sabarataan. 
Raja Biruang bapikir pulang satumat, imbah nitu inya baucap:

"Akur haja!, Taparukui haja aku!", ujar Raja (02/AGKAK/2006: 16-17).

["We take it to the opposite side of the continent that feather Hedgehog, I will drive him, give to the King of the elephants", says the kancil.

"Hauuuuuuu ....!", said all the animals.

The King of the bears think again, after which he said:

"Agree! I agree! ", says King] (02/AGKAK/2006: 16-17).

Excerpt [15], [16] and [17] shows the attitude and actions of the King of the bears in the lead democratic people's animals. The advice of the Falcon, the White Bird and be heard and approval of the kancil. The King of the bears gives the people's right to his opinion. This democratic attitude should be adopted because that way all the problems will be resolved and the aspirations of all people can be carried. Democratic characters found in the acts of Asalnya Gajah Kada Ada di Kalimantan (AGKAK).

\section{The Analysis Of Character Education}

Related To The Environment In The Folklore Of South Kalimantan

In this study found character education related to the environment i.e. form, a sense of love and care to the surrounding environment. Following the exposure of his analysis.

\section{Care For The Environment}

Care for the environment is the attitude and actions that are always working to prevent damage to the surrounding natural environment, there is a sense of love and developing efforts to repair damage to nature. The following excerpt.

[18] "Naya balasan aku kada tatahu lawan urang kampung, balalu aku musti manjaga kampung”, ujar Ning Kurungan.

"Kanapa garang?", ujar nang bini kada mangarti batambah bingung.

"Subuh kaina aku turun ka sungai badiam di luuk situ, manjaga kampung naya supaya jangan didatangi naga putih".

Bujur jua sakalinya, Ning Kurungan nang baubah jadi naga, wayah subuh nitu turun balangsar ka sungai tarus masuk ka dalam liang atawa luuk nang dalam nitu (06/KLN/2008: 35).

["This consideration I don't want know with people, then I have to take care of the village ", according to Ning Kurungan.

"Indeed, why? ", said his wife, who did not understand and increased confusedly.

"Later I went down to the river dawn lived in luuk that keep it from being visited the White Dragon".

It is also true it turned out, Ning Kurungan changed so the Dragon, when dawn came down to the river and get into a rut in it] (06/KLN/2008: 35).

This consideration I don't know menahu with villagers, then I have to take care of the village ", according to Ning Kurungan. When Ning Kurungan transforms into a dragon and he thinks that this is a reply for him for never hanging out with the villagers. Ning Kurungan stay in the rut and promises to keep it from being hometown on the visit by the White Dragon. 
The characters really need to care for the environment once owned by everyone. With care for the environment one can participate in preserving nature. The character of the care for the environment is found in the story Kisah Luuk Naga (KLN).

\section{CONCLUSION}

Based on the results of the analysis have been presented before, then researchers can adduce conclusions as follows.

1. Character education that relate to yourself in the folklore of the South Kalimantan there is some discussion, namely: a) the hard work which includes work gardening and planting rice, the struggling rescue someone, and not give up looking for fish, b) would like to know which includes figuring out a truth, c) charge that covers the responsibilities of a brother and the responsibility of a leader, d) independent that includes doing everything alone, and e) entrepreneur who includes a smart trade.

2. Character education that relate to our fellow human beings in the folklore of the South Kalimantan there is some discussion, namely: a) social care includes help to resolve a problem, help find the missing citizens, help treat a young child, and a fish that helped his friends, b) that includes the democratic free people's opinion, and c) obey that include a wayward child against the parents and a sister who dutifully against her sister.

3. Character education related to the environment in the folklore of the South Kalimantan care for the environment that includes someone who promised to keep the environment of the village.

\section{REFERENCES}

Koleksi Folklore Kalimantan Selatan. (2006). Banjarmasin: Lembaga Pendidikan Banua Banjarmasin

Koleksi Folklore Kalimantan Selatan. (2008). Banjarmasin: Lembaga Pendidikan Banua Banjarmasin

Kurniawan, Syamsul. (2013). Pendidikan Karakter. Yogyakarta: Ar-ruzz Media Ratna, Nyoman Kutha. (2015). Teori, Metode, dan Teknik Penelitian Sastra. Yogyakarta: Pustaka Pelajar

Seman, Syamsiar. (1936). Galuh Rumbayan Amas. Banjarmasin: Lembaga Pendidikan Banua Banjarmasin.

Seman, Syamsiar. (1999). Si Cupak Lawan Si Gantang Badua Baading. Banjarmasin: Lembaga Pendidikan Banua Banjarmasin. 